\title{
Analisis Kelayakan Usaha Pengolahan Ikan Asap di Kelurahan Faudu Kecamatan Pulau Hiri Kota Ternate
}

\author{
Haryati La Kamisi*a, Vanessa N J Lekahena** , Sandra L Hiariey* \\ * Staf Pengajar Prodi Agribisnis FAPERTA UMMU Ternate, Email: dinati.la@gmail.com \\ * Staf Pengajar Prodi THP FAPERTA UMMU Ternate, Email: - \\ *a Koresponden author : dinati.la@gmail.com
}

\begin{abstract}
ABSTRAK
Usaha pengolahan ikan asap merupakan usaha yang cukup menjanjikan dan memiliki peluang untuk dikembangkan karena di dukung oleh ketersediaan sumber daya ikan yang berlimpah serta biaya produksi yang rendah. Penelitian ini bertujuan untuk menganalisis penerimaan dan pendapatan serta kelayakan usaha dengan menggunakan kriteria investasi dari usaha pengolahan ikan asap di Kelurahan Faudu Kecamatan Pulau Hiri Kota Ternate. Total biaya investasi yang dikeluarkan dalam usaha pengolahan ikan asap sebesar Rp. 206.865.000,00. Total biaya produksi per tahun sebesar $R p$. 779.217.250,00 yang terdiri dari biaya tetap sebesar Rp. 3.777. 250,00 dan biaya variabel sebesar Rp. 775.440.000,00. Total penerimaan usaha pengolahan ikan asap per tahun sebesar Rp. 1.080.000.000,00 dengan pendapatan sebesar Rp. 300.782.750,00. Analisis kelayakan finansial menunjukkan bahwa usaha pengolahan ikan asap di Kelurahan Faudu layak dan menguntungkan dengan nilai NPV yang positif, sebesar Rp. 963.075.044.00; nilai IRR sebesar $145 \%$ atau lebih besar dari bunga bank yang berlaku saat ini yaitu 9\%; dan nilai Net B/C ratio sebesar 6.
\end{abstract}

Kata Kunci : Analisis kelayakan, ikan asap, usaha pengolahan.

\section{PENDAHULUAN}

Provinsi Maluku Utara sebagai provinsi kepulauan dengan luas laut 100.731,44 km2 (mencapai $\pm 76.28 \%$ dari total wilayah), memiliki potensi kelautan sangat dominan dan beragam. Potensi sumber daya perikanan tangkap pada wilayah tersebut sebesar 1.035.230 ton per tahun, dengan jumlah tangkapan bersih (JTB) sebesar 414.092 ton per tahun. Jenis ikan yang tersebar di wilayah perairan Maluku Utara adalah ikan pelagis besar (tuna, cakalang, tongkol, dan tenggiri) potensi per tahun sebesar 211.590 ton, ikan pelagis kecil (teri, kembung, layang, selar dan julung) dengan potensi per tahun sebesar 169.834,33 ton, jenis ikan demersal (kakap merah, lencan, baronang) sebesar $135.005,24$ ton per tahun.

Kesadaran masyarakat untuk memanfaatkan produk hasil perikanan dewasa ini semakin meningkat, hal ini di dorong karena peningkatan pengetahuan masyarakat tentang kandungan gizi ikan dan manfaatnya bagi kesehatan. Ikan merupakan bahan pangan yang mudah rusak dan mengalami penurunan mutu sehingga dapat menurunkan harga ikan itu sendiri sehingga perlu dilakukan upaya mempertahankan mutu dan memperpanjang umur simpan produk untuk dijadikan bahan konsumsi (Adawyah, 2007).

Pengolahan dan pengawetan merupakan salah satu bentuk upaya diversifikasi produk perikanan. Diversifikasi produk perikanan yang dilakukan bertujuan untuk meningkatkan nilai ekonomis produk hasil perikanan, memperbaiki cita rasa produk hasil perikanan, mempertahankan mutu, meningkatkan daya simpan produk, dan memperluas distribusi serta pemasaran produk (Zaelanie, 2004). Ikan asap merupakan salah satu cara pengolahan dan pengawetan ikan secara tradisional yang sangat komplek dan kondisi pengolahan yang 
tidak rasional, karena tidak terdapat standar tertentu yang harus dicapai (Heruwati, 2002). Pengasapan merupakan cara pengolahan dan pengawetan dengan memanfaatkan kombinasi teknik pengeringan dan pemberian senyawa kimia alami asap ke dalam bahan pangan, selain itu juga untuk mengawetkan atau menambah cita rasa (Winarno 2008; Adawyah, 2007).

Usaha pengolahan ikan asap banyak dilakukan oleh masyarakat Maluku Utara khususnya di Kota Ternate. Kecamatan Pulau Hiri, tepatnya di Kelurahan Faudu merupakan salah satu sentra produksi pengolahan ikan asap potensial yang terdapat di Kota Ternate. Usaha pengolahan ikan asap pada umumnya tergantung pada kondisi alam, sementara disisi lain pelaku usaha secara ekonomis harus profitable dan sustainable, sehungga perlu dilakukan analisis usaha untuk mengetahui dan menilai apakah usaha tersebut menguntungkan dan layak untuk keberlanjutannya di masa yang akan dating. Berdasarkan kondisi tersebut sehingga penulis tertarik untuk melakukan penelitian dengan judul: "Analisis Kelayakan Usaha Pengolahan Ikan Asap Di Kelurahan Faudu Kecamatan Pulau Hiri Kota Ternate".

Tujuan penelitian ini adalah untuk menganalisis penerimaan dan pendapatan serta kelayakan usaha dengan menggunakan kriteria investasi dari usaha pengolahan ikan asap di Kelurahan Faudu Kecamatan Pulau Hiri Kota Ternate.

\section{METODE PENELITIAN}

Penelitian ini berlokasi di Kelurahan Faudu Kecamatan Pulau Hiri Kota Ternate, yang ditentukan secara sengaja (purposive) karena lokasi tersebut merupakan salah satu sentra pengasapan ikan di Maluku Utara.

Jenis data yang digunakan dalam penelitian ini adalah data primer dan sekunder. Data primer diperoleh secara langsung dari sumber datanya melalui observasi, wawancara, dan kuesioner. Data sekunder diperoleh dari berbagai sumber yang telah ada seperti Biro Pusat Statistik (BPS), buku, laporan, jurnal, dan lain-lain yang berkaitan dengan penelitian ini.

Penentuan banyak sampel dalam penelitian ini menggunakan sampling jenuh, karena jumlah populasi penelitian ini sebanyak 30 orang atau relatif kecil sehingga semua jumlah populasi digunakan sebagai sampel. Hal ini sejalan dengan pendapat Sugiyono (2007) yang menyatakan bahwa sampling jenuh adalah teknik penentuan sampel dengan menggunakan semua populasi sebagai sampel karena jumlah populasi relatif kecil, tidak lebih dari 30 orang.

Metode analisis data pada penelitian ini yang digunakan untuk menentukan tingkat penerimaan dan pendapatan serta kelayakan usaha pengolahan ikan asap meliputi:

a. Analisis biaya untuk menghitung total biaya produksi (Soekartawi, 2006) dengan rumus:

$\mathrm{TC}=\mathrm{FC}+\mathrm{VC}$

Dimana: $\mathrm{TC}=$ Total Biaya

FC = Biaya Tetap

$\mathrm{VC}=$ Biaya Variabel

b. Analisis penerimaan dilakukan untuk menghitung total penerimaan (Soekartawi, 2006) dengan rumus:

TR $=$ Py $\times Q$

Dimana: $T R=$ Total Penerimaan

$$
\begin{aligned}
P y & =\text { Harga Jual } \\
Q & =\text { Total Produksi }
\end{aligned}
$$

c. Analisis pendapatan untuk menghitung total pendapatan (Shinta, 2011) dengan menurut sebagai berikut:

$\pi=\mathrm{TR}-\mathrm{TC}$

Dimana: $\pi=$ Total Pendapatan

TR $=$ Total Penerimaan

TC $=$ Total Biaya

d. NPV (Net Present Value) adalah selisih antara present value dari arus benefit dikurangi present value dari arus biaya (Pudjosumarto, 1991). Kriteria ini mengatakan bahwa proyek akan dipilih apabila NPV >0. Penentuan nilai NPV secara matematis (Shinta, 2011) dirumuskan sebagai berikut:

$\mathrm{NPV}=\sum_{t=1}^{n} \frac{(B t-C t)}{(1+i)^{t}}$

Dimana: $\mathbf{B t}=$ Benefit pada tahun ke-t

$\mathrm{Ct}=$ Biaya pada tahun ke-t

$t=$ lamanya waktu investasi

$\mathrm{i}=$ tingkat bunga

Jika: NPV $>0=$ usaha layak

$\mathrm{NPV}=\mathbf{0}=$ usaha impas

$\mathrm{NPV}<0=$ usaha tidak layak

e. Net B/C Ratio (Net Benefit/Cost Ratio) adalah penilaian yang dilakukan untuk melihat tingkat efisiensi penggunaan biaya 
berupa perbandingan jumlah nilai bersih sekarang yang positif dengan jumlah nilai bersih sekarang yang negatif (Gray, 1997). Suatu usaha layak dan efisien untuk dilaksanakan jika nilai Net $B / C>1$, yang berarti manfaat yang diperoleh lebih besar dari biaya yang dikeluarkan. Secara matematis Net $B / C$ ratio (Pudjosumarto, 1991) dirumuskan sebagai berikut:

Net B/C Rasio $=\frac{\sum_{i=1}^{n} \frac{B t}{(1+i) t}}{\sum_{i=1}^{n} \frac{C t}{(1+i)^{t}}}$

Dimana: $B t=$ Bebefit pada tahun ke-t

$\mathrm{Ct}=$ Biaya pada tahun ke-t

$i=$ tingkat bunga yang berlaku

$\mathbf{t}=$ jangka waktu proyek

$\mathrm{n}=$ umur proyek

Jika: B/C > 1 = Layak, B/C < 1 = Tidak Layak

IRR (Internal Rate of Return) adalah nilai discount rate (I) yang membuat NPV suatu usaha sama dengan nol atau dengan perkataan lain IRR menunjukkan present value (benefit) sama dengan present value (cost). IRR digunakan untuk mencari tingkat bunga yang menyamakan Bt pada nilai sekarang dengan $\mathrm{Ct}$ pada nilai sekarang di masa-masa mendatang (Soekartawi, 2006). Penggunaan Investasi akan layak jika diperoleh IRR yang persentasenya lebih besar dari tingkat suku bunga bank yang ditentukan, karena usaha berada dalam keadaan yang menguntungkan. Secara matematis IRR dirumuskan sebagai berikut (Pudjosumarto, 1991):

IRR $=i_{1}+\frac{N P V_{1}}{N P V_{1}-N P V_{2}}\left(i_{2}-i_{1}\right)$

Dimana: $\mathrm{NPV}_{2}=$ Perhitungan NPV positif mendekati nol dengan bunga modal sebesar i1 persen

$\mathrm{NPV}_{1}=$ Perhitungan NPV negatif mendekati nol dengan bunga modal sebesar $i_{2}$ persen

i1 = Discount factor (DF) pertama, tingkat bunga yang menghasilkan NPV positif

$\mathrm{i}_{2}=$ Discount factor (DF) kedua, tingkat bunga yang menghasilkan NPV negatif

Jika: IRR > Sosial Discount Rate = usaha layak, IRR $<$ Sosial Discount Rate $=$ usaha tidak layak

\section{HASIL DAN PEMBAHASAN}

\subsection{Analisis Biaya}

Total biaya investasi yang dikeluarkan dalam usaha pengolahan ikan asap di Kelurahan Faudu sebesar Rp. 206.865.000,00. Biaya investasi tersebut adalah untuk penyediaan ruang dan rak pengasapan serta pembelian peralatan penunjang produksi. Total biaya produksi usaha pengolahan ikan asap per tahun sebesar Rp. 779.217.250.00 yang terdiri dari biaya tetap sebesar Rp. 3.777.250,00 dan biaya variabel sebesar Rp. 775.440.000,00. Total pengeluaran terdiri dari pengeluaran untuk biaya tetap berupa biaya penyusutan peralatan per tahun dan pengeluaran untuk biaya variabel berupa biaya pembelian bahan baku ikan, bahan penolong dan upah tenaga kerja.

Analisis Penerimaan

Penerimaan (TR) adalah perkalian antara produksi yang diperoleh $(Q)$ dengan harga jual (Py). Total penerimaan usaha pengolahan ikan asap per tahun adalah rata-rata sebesar $R p$. 1.080.000.000.00.

\subsection{Analisis Pendapatan}

Pendapatan adalah selisih antara penerimaan (TR) dan semua biaya (TC). Jadi $\pi=$ TR - TC. Total pendapatan usaha pengolahan ikan asap per tahun adalah rata-rata sebesar $\mathrm{Rp}$. $300.782750,00$.

\section{a. Net Present Value (NPV)}

Nilai Net Present Value (NPV) menunjukkan nilai bersih usaha pada akhir umur ekonomisnya dengan menggunakan nilai suku bunga yang berlaku saat ini. Nilai NPV diperoleh dari selisih antara Present Value Cash Flow dengan total investasi. Perhitungan nilai NPV pada usaha pengolahan ikan asap menunjukkan nilai positif, yaitu Rp. 963.075.004,00. Hal ini menunjukkan bahwa usaha pengolahan ikan asap layak dijalankan karena nilai NPV > 0, yang artinya usaha tersebut dapat menghasilkan cash inflow dengan persentasi lebih besar dibandingkan opportunity cost modal yang ditanamkan (Rangkuti, 2004).

b. Internal Rate of Return (IRR)

Internal Rate of Return (IRR) menunjukkan kemampuan suatu usaha untuk menghasilkan returns atau tingkat keuntungan yang dapat dicapainya. Hasil perhitungan nilai 
IRR usaha pengolahan ikan asap yaitu $145 \%$ dan nilai tersebut jauh lebih besar dari bunga bank yang berlaku yaitu 9\%. Hal ini menunjukkan bahwa usaha pengolahan ikan asap feasible dan layak dijalankan karena menghasilkan tingkat pengembalian lebih besar dari suku bunga yang berlaku secara umum.

c. Net Benefit/Cost Ratio (Net B/C Ratio)

Net B/C Ratio atau analisis rasio keuntungan merupakan perbandingan antara tingkat keuntungan (benefit) bersih dari tahuntahun yang bersangkutan yang telah di-present value-kan (pembilang/bersifat positif (+)) dengan biaya bersih dalam tahun dimana $\mathrm{Bt}$ Ct (penyebut/bersifat negatif (-)) yang telah dipresent value-kan, yaitu biaya kotor < benefit kotor. Perhitungan nilai Net B/C Ratio usaha pengolahan ikan asap pada penelitian ini sebesar 6 yang berarti bahwa biaya yang dikeluarkan sebesar Rp. 1,00 akan memberi keuntungan sebesar Rp. 6,00. Nilai ini menunjukkan bahwa usaha pengolahan ikan asap layak dijalankan. Hal ini sesuai dengan pendapat Rahardi dan Hartanto (2003), yang menyatakan suatu usaha dikatakan layak dan memberikan manfaat apabila Net B/C Rasio lebih besar daripada 1 , semakin besar nilai Net B/C maka semakin besar pula manfaat yang diperoleh dari usaha tersebut.

\section{PENUTUP}

\subsection{Kesimpulan}

Usaha pengolahan ikan asap di Kelurahan Faudu Kecamatan Pulau Hiri Kota Ternate menguntungkan dan layak dijalankan dengan total biaya investasi sebesar $R p$. 206.865.000,00. Total biaya produksi per tahun sebesar Rp. 779.217.250,00 yang terdiri dari biaya tetap sebesar Rp. 3.777.250,00 dan biaya variabel sebesar Rp. 775.440.000,00. Total penerimaan per tahun sebesar Rp. 1.080.000.000,00 dengan pendapatan sebesar $R p$. 300.782.750,00. Hasil analisis kelayakan finansial menunjukkan bahwa usaha pengolahan ikan asap di Kelurahan Faudu layak dan menguntungkan karena memberikan nilai NPV yang positif, yaitu sebesar $R$. 963.075.044,00; nilai IRR sebesar $145 \%$ atau lebih besar dari bunga bank yang berlaku yaitu 9\%, dan nilai Net B/C Ratio yaitu sebesar 6 .

\subsection{Saran}

Perlu adanya proses pendampingan, pembinaan dan pelatihan terhadap usaha pengolahan ikan asap secara intensif dan berkelanjutan agar pelaku usaha dapat memanfaatkan sumberdaya yang tersedia secara optimal dan mampu menerapkan teknologi tepat guna dalam pengolahan produk sehingga menghasilkan produk ikan asap yang memenuhi standar SNI dan meningkatan manajemen usaha.

\section{UCAPAN TERIMA KASIH}

Penulis mengucapkan terima kasih kepada Dirjen DRPM Kementrian Riset, Teknologi dan Pendidikan Tinggi, yang telah membiayai kegiatan Pengabdian Kepada Masyarakat pada skema Iptek bagi Masyarakat (IbM) tahun anggaran 2015.

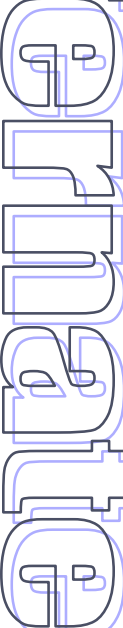

\section{DAFTAR PUSTAKA}

Adawyah R. 2007. Pengolahan dan Pengawetan Ikan. PT. Bumi Aksara. Jakarta.

Gray C. 1997. Pengantar Evaluasi Proyek. Edisi Kedua. PT. Gramedia Pustaka Utama. Jakarta.

Pudjosumarto M. 1991. Evaluasi Proyek: Uraian Singkat dan Soal-Jawab. Liberty. Yogyakarta.

Shinta A. 2011. Ilmu Usahatani. UB-Press. Malang.

Soekartawi. 2006. Analisis Usahatani. UI-Press. Jakarta.

Sugiyono. 2007. Statistika untuk Penelitian. CV. Alfabeta. Bandung.

Rahardi F, Hartanto R. 2003. Agribisnis Peternakan. Penebar Swadaya. Jakarta

Rangkuti F. 2012. Study Kelayakan Bisnis dan Ivestasi. Kompas Gramedia Building. Jakarta

Winarno FG. 2008. Kimia Pangan dan Gizi. Ed. Terbaru. M Brio Press. Jakarta.

Zaelanie K, Nurdiani R, Dayuti S. 2004. Teknologi Hasil Perikanan I. Fakultas Perikanan Universitas Brawijaya. Malang. 